\title{
MOTIVATION IN ANDREA HIRATA'S NOVEL THE RAINBOW TROOPS
}

\author{
Wahyu Fatahilla, M. Manugeren, Purwarno Purwarno \\ Faculty of Literature, Universitas Islam Sumatera Utara \\ Medan, Indonesia \\ e-mail: wahyu.fatah007@gmail.com
}

Received: 2020-11-08

Accepted: 2020-11-23

\begin{abstract}
This research is concerned with the motivation in Andrea Hirata's novel The Rainbow Troops. The novel is also a reflection of the biographical sketches of the author. The objectives of the study are to identify the kinds of motivations reflected in The Rainbow Troops' novel and to describe the motivations developing in "The Rainbow Troops" novel. Motivation is a direction and also energy for people to do everything included learning something. The researcher uses descriptive qualitative method in this study with the aim at describing a place, fact and characteristics of population systematically, factually and accurately. This research method is also appropriate to expose social phenomena. The data are in the forms the text and quotation from the novel containing motivation. The results of research show that there are two kinds of motivations found in the novel: extrinsic and intrinsic motivations. Extrinsic motivation consists of never giving up and education and attitude needs to be learned; for intrinsic: hard work for education, and honesty.
\end{abstract}

Keywords: motivation, education, attitude, honesty

\section{Introduction}

Literary works give lessons of life for the readers. Those things can also be found in a novel as a kind of literary works. A novel is a reflection of life. In a novel, the readers can find realities and valuable things of life that will give them more understanding about life and the problems of it. Messages are also the important things that the readers can get from a novel. The readers usually can find the whole messages from the character who play the role. It can be done by analyzing the motivation of the main characters and how the main characters are characterized. This is in line with Purwarno (2019) stating that literature is a reflection of time and society.

This study is based on an novel, entitled Laskar Pelangi written by an Indonesian novelist, Andrea Hirata. This novel has a translated version, entitled: The Rainbow Troops, translated by Angie Kilbane. The novel tells a story about a boy named Ikal and his nine friends who fight for their education and dignity although their family are in poverty and they often face difficult situations. Ikal and his nine friends study at a school in the poverty-stricken Gantong village in Belitong, Indonesia, named Muhammadiyah primary school. The poverty of the native people in Belitong is an irony because at that time Belitong is the richest island in Indonesia, or maybe even in 
the world because their land contains an enormous amount of tin. At that time, a handful of tin is worth more than dozens of buckets of rice. This novel is based on the true story of the author, Andrea Hirata born in Gantung, Belitung. While he was young, his parents changed his name seven times. They eventually settled on the name Andrea, while the name Hirata was given by his mother. He grew up in a poor family not far from a government-owned mine.

Hirata started his tertiary education with a degree in economics from the University of Indonesia. After receiving a scholarship from the European Union he did his master's degree in Europe, first at the University of Paris then at Sheffield Hallam University in Britain; his thesis dealt with telecommunications and the economy. Andrea Hirata released The Rainbow Troops in 2005. The novel, was written in a period of six months, and was based on his childhood experiences in Belitung; he later described it as an irony about a lack of access to education for children in one of the world's wealthiest islands. The novel went on to sell five million copies, with pirated editions selling 15 million more.

The focus goes to motivation. There are two types of motivation, such as; extrinsic and intrinsic. Extrinsic motivation, refers to doing something because it leads to a separable outcome and intrinsic motivation refers to doing something because it is inherently interesting or enjoyable, (Maslow: 1994). The points of discussion for extrinsic motivation are never giving up and education and attitude needs to be learned; for intrinsic: hard work for education, and honesty.

Thus, motivation is someone's reason to do or not to do something to get the goal. The reasons to do something can be done because it is enjoyable or because the doer wants to get an outcome. Motivation plays important role in making someone's dreams come true. By reading and analyzing the novel especially motivation, it is expected that the researcher would apply them at campus or school.

\section{Literature Review}

\subsection{Motivation}

Motivation is a common word for people nowadays. It can be seen through some seminars, and television programs. These programs motivate people to have a better life sight and also push them to be better than before. For this study, the researcher needs to know what motivation is for her own understanding to do the research latter.

Alderman (2004) state that motivation as sufficient reason to behave as they do. Motivation leads human to take action. Motivation can push someone to do something that they want. According to Dornyei (1994) motivation comes from the Latin word "motive" which mean "to move" is defined in many different ways, the most common one is a series of questions that why people think, feel, and behave as they do. Alderman (2004) distinguishes motivation from the other factors that also influence behavior, such as the past experience of a person, the physical capabilities, and the environmental situation in which a person finds himself.

According to Franken (2003) motivation theorists start with the assumption that, for every behavior, there is a cause. Their goal is to identify those causes. Higgins in Franken"es Human motivation states that psychologist distinguish between approach causes and avoid an causes. In approach behavior, people do things because of something they want, desire, or need. This is often conceptualized in terms of a specific goal object. In avoidant behavior, people do things to avoid something. Motivation is a factor within an individual (such as needs, desires, and interests) that activates, 
maintains, and directs behavior toward a goal. It indicates that people are motivated to do something because they have a goal or purpose.

As stated literally, motivation is an enthusiasm or need for doing something. Theorists actually have their own understanding what motivation is. Most of them have the same perception. According to Woolfolk (2007:345), motivation is usually defined as an internal state that arouses, directs, and maintains behavior.

Motivation helps the researcher concludes that motivation can be a reason for someone to do something or practice. In a statement Santrock (2000:86) states the example of it as follow; "If students don't complete an assignment because they are bored, lack of motivation is involved. If students encounter challenges in researching and writing a paper, but persist and overcome hurdles, motivation is involved." As Santrock gives examples above, the researcher concludes that motivation include in good learning process.

That means motivation can be as the key for the successful learning. The failure of successful planning process can be caused by there is no motivation. It can be seen that motivation is important in learning process. The role of motivation in achievement based on many researchers is the key component. The researcher concludes that motivation generally as energy to support all goals that humans have made. Motivation can be as a guidance to take some efforts to achieve what the people want. A motivation is a state of a cognitive arousal which provokes a "decision to act" as a result of which there is ,sustained intellectual and/or physical effort" so that the person can achieve some ,previously set a goale. Motivation is some kinds of internal drive which pushes someone to do things in order to achieve something. This definition is introduced in some theories, the most widely known are motivation to learn, to work, and get achievement.

Motivation also has the factors which can influence how the motivation can be decreased or increased in the learning process. The researcher gets this understanding from Hamalik (2019) pointing out that the influence of motivation are; (a) students' awareness of their learning goals, (b) teachers' attitude to their students in class can be as intrinsic or extrinsic motivation, (c) influence from students' group, and (d) class environment. The writer gets the points from this theory that motivation in learning is influenced by students' self, the teachers, and also students' environment. All of these roles are have their own influences to make motivation exist. Due to the existence of motivation, the successful learning can be achieved. This theory has same meaning with Dornyei's (1994:51) that the researcher has mentioned in the previous part that is stated "motivation is one of the main determinants of second/foreign language learning achievement." As mention above, one of influence factors of motivation is the class environment. It makes the researcher interested in finding out more how motivation is in class.

\subsection{Kinds of Motivation}

Motivation can be divided into two kinds. These kinds of motivation are divided through how the motivation arrives and the influences around the person itself. They are extrinsic motivation and intrinsic motivation, Sumadi (2018). Extrinsic motivation which found in this research are talking about the education environment and how the effort of children to reach their dream with the bad school and lack of facility in their village "Belitong". While, intrinsic motivation can be understood from the analysis, such as: how they create something, to win a competition, and to be a confident man. 


\subsubsection{Extrinsic Motivation}

To get more understanding about extrinsic motivation, the writer found out some theories that help her to understand. Sumadi (2018) defines extrinsic motivation as below:

Extrinsic motivation involves doing something to obtain something else. Extrinsic motivation is often influenced by external incentives such as rewards and punishments. For example, a student may study hard for a test in order to obtain a good grade in the course.

Motivation can be stated as extrinsic motivation in condition of external influenced. The influences can be rewards and punishments. For example, the boy studied hard due to his father will give him the new robot as his reward in getting best score. It is same as Alderman (2004) stating that "Extrinsic motivation occurs when students engage in activities for external reasons (outside of themselves) such as praise, grades, special privileges, and certificates or material rewards."

In a book named Intrinsic and Extrinsic Motivation, Abuddin (2019) the researcher finds that extrinsic motivation has different perspective to know what extrinsic motivation is as follows:

... .Two distinct definitions of extrinsic motivation appear to have emerged: (1) when motivation is based on something extrinsic to the activity and (2) when motivation is based on something extrinsic to the person.

The author of this book thinks that extrinsic motivation happens in two kinds of condition. It is based on outside of the activity and also from the person. It can be deduced that extrinsic motivation is a type of motivation that comes from outside of the people themselves. In the learning process, extrinsic motivation can come from the teachers' reward for their students, praising, or others. It makes the motivation as drive in learning process.

Addition, extrinsic motivation is learning activity that occurs from the encouragement and someonee s need that absolutely not related to the activities of their own learning. It is caused by any number of outside factors. For example: the need to pass an exam, financial reward, good mark, etc.

Some opinions state that the concept of intrinsic motivation occurs when extrinsic motivation is fulfilled. Extrinsic motivation itself is basically a behavior that is driven by external forces of the individual. Individual motivated extrinsically if that individual chooses an easy task, routine, simple and predictable, working to get prize, depending on help of others, less confident to express their opinions, and using external criteria in determining success and failure. Here, as an example extrinsic motivation portrayed from $\mathrm{Bu}$ Muslimah characters.

Being a teacher in Muhammadiyah Gantong primary school is a moneyless profession. Eventhough Bu Mus can still help the school with her own money.

Bu Mus fulfilled Mister Samadikun ${ }^{e e}$ s trivial and finicky requirements: calculator, compasses, and crayons. She was able to buy a few compasses and some crayons with money from her money from her sewing. And because calculators were very expensive, she bought an abacus instead. The important thing, however, was that we now had 
two trophies that would certainly impress Mister Samadikun (Hirata: 2005).

The text above obviously shows that Bu Mus is very helpful person. It is analyzed by using Sumadi's theory (emergency motivation which incuded to extrinsic motivation). She wants to teach her student moneyless, even she gives her money for helping their school. It is derived from $\mathrm{Bu}$ Mus reaction to face the situation and problem in Belitung's students.

On the other hand, the character of Ikal has a great effort (external motivation) will and determination if he wants something. One was when he got a scholarship to go to abroad. It was not separated from his determination. In order to get a scholarship, he did whatever he could. It was seen from the quotes below:

"I finished my undergraduate courses quickly and, without wasting any time at all, I grabbed the application for the European Union scholarship. I didn't spend even a minute on anything other than studying for the scholarship test. I read as many books as I could. (Hirata: 2005)

\subsubsection{Intrinsic Motivation}

According to Santrock (2000: 46), "intrinsic motivation involves the internal motivation to do something for its own sake. For example, a student may study hard for a test because she enjoys the content of the course." It means that intrinsic motivation comes from inside of the person. Alderman (2004: 231) also defines that "intrinsic motivation is typically defined as students engaging in actions for their own sake and without coercion such as satisfaction, interest, learning, and challenge." With intrinsic motivation, the students don't need to be pushed in doing something.

This statement is same with this next statement that "Intrinsic motivation describes self-initiated task engagement with no apparent extrinsic rewards beyond the activity itself." The researcher also finds that "a number of researchers define intrinsic motivation as occurring when an activity satisfies basic human needs for competence and control, which makes the activity interesting and likely to be performed for its own sake rather than as a means to an end." It means that intrinsic motivation can be a parameter to someone in doing the job. If the person feels interesting to do learning, it means that he/she has the intrinsic motivation.

The researcher deduces that intrinsic motivation is an energy that the people got from inside of themselves. This energy never got influence from the outside. This motivation can be as a satisfaction for the people themselves. The interesting in learning or do something is the indicator that a person has intrinsic motivation.

Each of us is motivated by needs. Our most basic needs are inborn, having evolved over tens of thousands of years. According to Maslow (1994: 30) the underlying of human behavior are basic needs that can be arranged in a hierarchy. The lowest level are physiological need (food, drink, sleep, cloth, shelter, etc), the next level are safety needs (stability, low, safe from fear, etc), love and belongness needs, selfesteem needs (achievement, competence, recognition, etc), and the most upper level are self-actualization needs. 


\section{Research Method}

Research design is presenting the methodology which is used by the researcher to analyze the data. This is very important to do a research, the researcher need to apply the right method. The method which is used in this research is qualitative method. Descriptive analysis means to describe what actually happen to procedures about method which are useful in research. Descriptive approach does not apply the detail arithmetic calculation or statistic contains sentences or description of the objects (Moleong: 2011).

The researcher uses descriptive qualitative method in this study, because the data are form the text of the novel by Andrea Hirata "The Rainbow Troops" which contain motivations in his novel. The main data of the analysis are taken from the phrases, sentences and the first existed in the novel "The Rainbow Troops". The secondary data are taken from the other references, as books, articles and book review.

The aim of descriptive qualitative method is to describe a place, fact and characteristic of population systematically, factually and accurately. Descriptive qualitative method employs technique of seeking, collecting and analyzing data. The analyses in qualitative research concern in understanding the result of found data rather than calculate the result of found data (Moleong: 2011)

\section{Results and Discussion}

\subsection{Extrinsic Motivation}

Extrinsic motivation is the outside of the literary works, but they indirectly affect the organization system of literary work. More specifically, they can be considered as elements that affect the story of a literary work, but it does not come to be parts of it. The extrinsic elements in literary works are like background of authors, problems in social life, culture, destiny, getting knowledge and dreams.

\subsubsection{Never Giving Up}

Being a teacher in Muhammadiyah Gantong primary school is a moneyless profession. Eventhough Bu Mus can still help the school with her own money. Bu Mus fulfilled Mister Samadikun 's trivial and finicky requirements: calculator, compasses, and crayons. She was able to buy a few compasses and some crayons with money from from her sewing. And because calculators were very expensive, she bought an abacus instead. The important thing, however, was that we now had two trophies that would certainly impress Mister Samadikun, (Hirata, 2005:335).

The text above obviously shows that Bu Mus is a very helpful person. Under Sumadi's theory (2018), it is analysed that Bu Mus has a big motivation to teach her student. Bu Mus has an empathy to see the situation and problem faced by students in Muhammadiyah Gantong primary school. below:

The next motivation presented in the novel can be seen seen in the quotation

"Pak Harfan were worried about being shut down, while the parents were worried about expenses, and we have the nine small children caught in the middle were worried we may not get to go to school at all." (Hirata, 2005:5) 
The above quotation delivers the lesson that whatever the problem or obstacle occurs in our life, we have to be able to face every case patiently because it will make us survive and give us wisdom in the future. This is the way how Pak Harfan always keeps motivating himself, that he never gives up whatever the problem is. He believes that the miracle is gifted by God. Based on the rules of the government, Muhammadiyah school will be closed if the number of the students is less than ten. The time comes that the school is still lack of students. Suddently, the miracle comes, as shown in the quotation below:

"Trapani yelled and pointed to the edge of the schoolyard, startling everyone. "Harun!" Immediately, we all turned to look, and off in the distance was a tall, skinny boy, clumsily headed our way. His clothes and hairstyle were very neat."

(Hirata, 2005:7)

It is Harun. The boy who comes as registered student to complete the ten in number, then the school is saved by the boy. Harun is a funny boy who has mental illness. He is 15 years old. If Harun does not come as a student in SD Muhammadiyah, the goverment will close that school because SD Muhammadiyah must have ten students. It means that, Harun becomes a last student in this school and the number of students has been enough according to the requirement of government in this region.

Next quotation shows us pak Harfan's ways to give message to Muhammadiyah's students honestly and patiently, "Pak Harfan seems very happy face his student." (Hirata, 2005:23)

The above quotation shows the attitude of Pak Harfan facing the problem and giving them topic of the study with different characters. Life always seems to present us with innumerable challenges and problems on a daily basis. It throws left hooks when we are expecting right ones; it gives us apples when we desire oranges; it even presents us with seemingly awful surprises that we are not expecting, and it bloats us with unresourceful emotions that tend to tie us down to a life of mediocrity and unhappiness.

Despite all this, it is not so much what happens to us that actually makes a difference, it is rather what we do with what happens to us that determines where we will end up, what we will have, and how we will be transformed by our experiences. Furthermore, next motivation in this novel can be reflected from Lintang, Ikal, Sahara wins the Academic Challenge with the PN school. But before that, they come through with their own worries whether they lose or win, because this competition is very big and in large scale, as shown by the quotation below:

"The risk here was higher than the one we faced in the carnival. The Academic Challenge was an open arena to demonstrate intelligence or, if you were unlucky, an unthinkable amount of stupidity. All the bad luck would be borne by me, Shara and Lintang. We were team $\mathrm{F}$ in this button-pushing competition. What if we couldn't answer and come home with no points? It would be humiliating!" (Hirata, 2005:297298)

At first Ikal or Andrea is really scared if they do not get enough points to win the competition. Ikal has wrong answer to the question and that events really trigger the worries in Ikal's mind as shown by the quotation below:

"With absolute certainty, I hit the button and shoutedout, "The Chinese national anthem" And I was wrong, "Minus one hundred" 
Everyone cursed me. How foolish.It was clear from the name itself the answer was Thailand." (Hirata, 2005:306)

From the quotation, it is clear that Ikal really curses himself about the answer. But Lintang and Sahara do not blame Ikal for the wrong answer but rather than they spark Ikal some courageous sentences and then Lintang calmly answers all the questions that make their team the winner.

"Our supporters roared and jumped for joy. We won! I couldn't believe it - our Muhammadiyah village school won! I hugged Lintang. He threw his hands up high. We jumped up and down merrily." (Hirata, 2005: 309)

From the quotations above, it can be concluded that whatever the problems are, we must never give up because there is always a ways to overcome a problem whether solved by ourselves or by the support of our friends.

\subsubsection{Education and Attitude Needs to be Learned}

Education and attitudes are the important things and interdependent on each other as shown by the quotation below:

"He was a guru in the true sense of the word, its Hindi meaning: a person who not only transfers knowledge but who also is a friend and spiritual guide for his students."

(Hirata, 2005:23)

It shows that Pak Harfan's ways to give the lesson to his student is not only as a teacher who gives the knowledge to his /her students, but also as a friend and teaches religion to his students. A human besides as a individual one, can be called as social creature which cannot be separated from other people and basically humans are made by God in order that they can help one another. The statement above can be seen below:

"Give something to other people, does not receive from another people. " (Hirata, 2005: 24)

The quotation above is a message from Headmaster to his students. Education is a form of attitude which refers to the personality, like right or wrong ethic. It can be seen from quotation below:

"Send the children to school, it means that tie ourselves for cost till some years and this case is not easy for our family."

(Hirata, 2005:3)

It indicates that the education needs a big cost for some years and all the cost is the parents' duty which must be responsible for by them.

"This morning, they must be in the school for avoiding society 'because they do not send their children to school or as a people which is trapped for make their children not become stupid."

(Hirata, 2005:3)

The quotation above shows that according to the society if the children do not get the chance to school, they will lack of attitude and their parents will be blamed for 
not sending them to school. The next quotation below is about Sahara who wants to study in Muhammadiyah.

"Sahara cried hold his mother because she wants school in Muhammadiyah.”. (Hirata, 2005:6)

\subsection{Intrinsic Motivations}

\subsubsection{Hard Work for Education}

Education is the one basic need for each of individual to catch on dream. In order for Lintang to get education, he goes through subdistrict where he goes to school by using bicycle very early in the morning. Look at this quotation: "Ah! the small child like that." (Hirata, 2005:11). It means that somebody who wants to get the education should not be adult, a small child like Lintang can get education as far as we have the strong desire. Education must be had by every person.

"It's not exaggeration to say that Lintang often risked his life for the sake of his education. Nevertheless, he never missed a day of school. He pedaled 80 kilometers roundtrip every day. If school activities went until late in the afternoon, he didn't arrive home until after dark. Thinking about his daily journey made me cringe"

(Hirata, 2005:77)

The above quotation shows that Lintang really wants to get education that he really works hard to acquire it. Bu Mus has a big responsibility while Lintang as a student has right and duty, although he faces many obstacles to school but Lintang never gives up to getthe best education from Muhammadiyah School.

"The knowledge gives me the braveness forward some steps more." (Hirata, 2005:88)

Education is one of the things that people learn through hard work. The quotation below shows that Lintang has a high spirit to take any challenge for the sake of education

"The distance wasn't the only difficult to be faced. During the rainy season, chest-deep waters flooded the roads. When faced with a road that turned into a river, Lintang left his bicycle under a tree on higher ground, wrapped his shirt, pants and books in a plastic bags, bit the bag, plunged into the water, and swam toward school as fast as he could to avoid being attcked by a crocodile."

(Hirata, 2005:77)

People will have their own ways to get education to be learned without being obstructed. Lintang also has a desire to wake up early without the clock by his side, like quotation below:

"Because there was no clock at his house, lintang relied on a natural clock". (Hirata, 2005:77)

\subsubsection{Honesty}

The next moral lesson is about right thinking in Muhammadiyah School which explains about the character in Islam from Amir. Amir is strict or rather mean as a leader, as shown by the quotation below: 
"Whoever that we show as a Amir and we have given the salary for it, so whatever that they take except from his/her salary is called as a liar." (Hirata, 2005:71)

The above quotation shows that Bu Mus hates corruption very much and she reminds her students that they must be honest and also the leader will take their responsibility in the hereafter later. In the next quotation, we can see other moral value which is found by Ikal in Muhammadiyah Belitung School, as shown below:

"In this school, I can understand about honestly, the struggle and integrity." (Hirata, 2005:84)

The above quotation shows how Ikal feels to Muhammadiyah School which is not only teaching about honestly, struggle, and integrity but also teaching about a big idea of a Moslem.

It's not enough, the prior of institution gives the learn which is very important about the big idea of Moslem, the braveness for applying the idea, although many problem is happened and the concept of life by using statement give the advantages to other people through sacrifice without reward. (Hirata, 2005:85)

This quotation shows that praising that is given by Ikal to the teacher who has given much knowldedge about Moslem is very useful for him and to another group of The Rainbow Troops and also teaches them how they can face a case patiently, then gives the advantage to other people without any reward.

\section{Conclusion}

One framework used for understanding motivation is that humans are inherently motivated to better themselves and move toward expressing their full potential, selfactualization, by progressively encountering and satisfying several levels of need from the most fundamental, such as for food and safety, to higher-order needs for love, belonging, and self-dignity. Motivation is often the result of action, not the cause of it. Getting started, even in very small ways, is a form of active inspiration that naturally produces momentum. Motivation involves the biological, emotional, social, and cognitive forces that activate behavior. In everyday usage, the term "motivation" is frequently used to describe why a person does something. It is the driving force behind human actions and through the research results it is found that there are two forms of motivation, extrinsic and intrinsic motivations. For extrinsic motivation, never giving up and education and attitude needs to be learned are found and for intrinsic motivations, hard work for education and honesty.

\section{References}

Abuddin, Nata. (2019). Pengembangan Profesi Keguruan. Depok: Rajawali Pres.

Alderman, M. Kay. (2004). Motivation for Achievement-Possibilities for Teaching and Learning, 2nd Edition, New Jersey: Lawrence Erlbaum Associates, Inc.

Dornyei's, Yun. (2004). Motivation, Emotion, and Cognition -Integrative Perspective on Intellectual Functioning and Development-, New Jersey: Lawrence Erlbaum Associates, Inc.

Franken, Woeht. (2003). Character of Motivation. Cambridge: Unc Int. 
Hirata, Andrea. (2005). The Rainbow Troops. Jakarta: Gramedia.

Maslow, Kennedy. (1994). Instrinsic Concept on Motivation. New Jersey: Exv. Print.

Moleong, Lexy. J. (2011). Metodologi Penelitian Kualitatif. Bandung: PT. Remaja Rosdakarya.

Purwarno, et.al. (2019). Medieval Religious Officials in Geoffrey Chaucer's Prologue to Canterbury Tales" in The Second Annual International Conference on Language and Literature, $\mathrm{KnE}$ Social Sciences. Retrieved from DOI 10.18502/kss.v3i19.4887

Santrock, Sansone. (2000). Intrinsic and Extrinsic Motivation-The Search for Optimal Motivation and Performance-, SanDiego: Academic Press.

Sumadi, Suryabrata. (2018). Psikologi Pendidikan. Depok: Rajawali Pers.

Woolfolk, Anita. (2007). Educational Psychology, 10 $0^{\text {th }}$ Edition, Boston: Pearson Education, Inc. 